The recommendations can be summarized as follows:

I) The young bulls should be used randomly with respect to mates, herds and regions.

2) Only reliable figures should be published, minimum requirements are given.

3) The progeny test results of a bull should be expressed as Breeding Value. For traits of minor importance an appreciation of the Breeding Value in positive, medium and negative can be done.

4) The following information should be available, from the bull himself: identity, pedigree, body measurements, performance test, fertility of the semen; from the progeny: lactation yield (milk, protein, fat), beef test results, ease of milking, type and udder conformation, calving performance (direct and indirect effects) and fertility of the daughters.

5) The calculation of a selection index is highly recommended.

6) Some suggestions are made regarding the export of semen in other countries.

\title{
COMPARISON OF SEVERAL SIRE EVALUATION METHODS IN DAIRY CATTLE BREEDING
}

\section{Dempfle. - Lehrstuhl für Tievaucht der Technischen Universität München D-805oFreising- Weihenstephan.}

The objectives of sire evaluation are discussed where AI is used but herd sizes are small. In every evaluation scheme, the question arises what kind of information should be used apart from daughter records. Further, we have to consider whether it is worthwhile to wait for the second lactation of the daughters. In sire evaluation, we are nearly always concerned with several traits, and the usual way of getting the aggregate genetic economic value of an animal is by the application of an index ignoring any correlations between traits. Though that is not optimal, the loss in efficiency is unlikely to be large. Another important point is the determination of the appropriate classification within which the comparison should be made, e. g. should we use herd-year-seasons or herd-years or even group the herds by mean yields. The herdmate method, the contemporary comparison method, the modified cumulative difference method, least squares, regressed least squares and BLUP are discussed, and their relationship with each other is pointed out.

\section{INVESTIGATIONS ON RANKING OF PROGENY TESTED BULLS}

\section{J. Dону and E. Guba. - Agricultural College, 7400 Kaposvar, Hungary.}

It has been studied the order of progeny tested bulls, ranked on basis of: I. milk fat $\mathrm{kg}$; 2. FCM kg; 3. milk fat + milk protein kg; 4. FCM kg: I oo kg body weight; 5 . (milk fat + milk

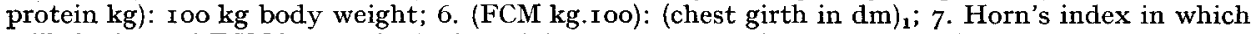
milk fat $\mathrm{kg}$ and FCM $\mathrm{kg}$ : Ioo $\mathrm{kg}$ body weight are asserted with weighting of 50:50 per cent. Data of so per cent and 4 per cent of the best sires out of 55 Red Danish bulls (progeny tested in Denmark) were analyzed. It was found that: $I$. the ranking of the best bulls according to various traits of absolute and relative production may lead into different classification. Selection among the best sires on basis of milk fat $\mathrm{kg}$, or FCM kg, resp. milk fat + milk protein $\mathrm{kg}$ seems to be equally effective concerning milk fat + milk protein quantity in average of the best 4 to 10 per cent of the progeny groups. The average milk fat + milk protein production $(\mathrm{kg})$ of the best groups has been found to be $I$ to 6 per cent less, if selected according to relative milk production than in case of ranking according to absolute production. 2. The average relative milk production of the best progeny groups has been found 2 to 3 per cent higher, if selected directly according to relative production. - It has been proposed to take the index of relative milk production per day of life into consideration regarding the ranking progeny tested bulls of dairy type. For ranking dual-purpose sires it was proposed a method in which milk fat kg, milkability and av. daily gain of fattened male progenies should be taken into consideration, on basis of evaluation numbers for each trait. - It was found that, to sort out ro to 20 per cent of the lowest producing individuals of each progeny group, is permissible, without losing the possibility of identification of the best and worst bulls. 